\title{
Isolation, characterization, and cryopreservation of collared peccary skin-derived fibroblast cell lines
}

\author{
Alana Azevedo Borges ${ }^{1}$, Gabriela Pereira de Oliveira Lira ${ }^{1}$, Lucas Emanuel Nascimento ${ }^{1}$, Maria Valéria de Oliveira \\ Santos $^{1}$, Moacir Franco de Oliveira ${ }^{2}$, Alexandre Rodrigues Silva ${ }^{3}$, Alexsandra Fernandes Pereira ${ }^{\text {Corresp. } 1}$ \\ 1 Laboratory of Animal Biotechnology, Federal Rural University of Semi-Arid, Mossoró, Rio Grande do Norte, Brazil \\ 2 Laboratory of Applied Animal Morphophysiology, Federal Rural University of Semi-Arid, Mossoró, Rio Grande do Norte, Brazil \\ 3 Laboratory of Animal Germplasm Conservation, Federal Rural University of Semi-Arid, Mossoró, Rio Grande do Norte, Brazil \\ Corresponding Author: Alexsandra Fernandes Pereira \\ Email address: alexsandra.pereira@ufersa.edu.br
}

Background. Biobanking of cell lines is a promising tool of support for wildlife conservation. In particular, the ability to preserve fibroblast cell lines derived from collared peccaries is of significance as these wild mammals are unique to the Americas and play a large role in maintaining the ecosystem. We identified collared peccary fibroblasts by immunofluorescence and evaluated their morphology, growth, and adherence capacity. Further, we monitored the viability and metabolic activity of the fibroblasts to determine the effects of passage number and cryopreservation on establishment of cell lines.

Methods. Skin biopsies were collected from the peripheral ear region from five adult animals in captivity. Initially, cells were isolated from fragments and cultured in the Dulbecco's modified Eagle medium (DMEM) supplemented with $10 \%$ fetal bovine serum and $2 \%$ antibiotic-antimycotic solution under a controlled atmosphere $\left(38.5^{\circ} \mathrm{C}, 5 \% \mathrm{CO}_{2}\right)$. We evaluated the maintenance of primary cells for morphology, adherence capacity of explants, explants in subconfluence, cell growth, and absence of contamination. Moreover, we identified the fibroblast cells by immunofluorescence. Additionally, to evaluate the influence of the number of passages (first, third, and tenth passage) and cryopreservation on establishment of cell lines, fibroblasts were analysed for the viability, metabolic activity, population doubling time (PDT), levels of reactive oxygen species (ROS), and mitochondrial membrane potential $(\Delta \Psi \mathrm{m})$.

Results. All explants (20/20) adhered to the dish in 2.4 days \pm 0.5 with growth around the explants in 4.6 days \pm 0.7 , and subconfluence was observed within 7.8 days \pm 1.0 . Moreover, by morphology and immunocytochemistry analyses, cells were identified as fibroblasts presenting oval nuclei, a fusiform shape, and positive vimentin staining. No contamination was observed after culture without antibiotics and antifungals for 30 days. While no difference was observed for cell viability after the passages (first vs. third: $P=0.98$; first vs. tenth: $P=0.76$; third vs. tenth: $P=0.85$ ), metabolic activity was found to be reduced in the tenth passage $(23.2 \% \pm 12.1 \%)$, when compared to that in the first and third passage $(100.0 \% \pm 24.4 \%, P=0.006)$. Moreover, the cryopreservation did not influence the viability $(P=0.11)$, metabolic activity $(P=0.77)$, or PDT $(P=0.11)$. Nevertheless, a greater $\Delta \Psi \mathrm{m}(P=0.0001)$ was observed for the cryopreserved cells $(2.12 \pm 0.14)$ when compared to that in the non-cryopreserved cells ( $1.00 \pm$ 0.05). Additionally, the cryopreserved cells showed greater levels of intracellular ROS after thawing (1.69 \pm 0.38 vs. $1.00 \pm 0.22, P=0.04)$.

Conclusions. This study is the first report on isolation, characterization, and cryopreservation of fibroblasts from collared peccaries. We showed that adherent cultures were efficient for obtaining fibroblasts which can he used as donor cells for nuclei for species cloning and other applications. 


\section{Isolation, characterization, and cryopreservation of collared}

\section{2 peccary skin-derived fibroblast cell lines}

3

4 Alana A Borges ${ }^{1}$, Gabriela PO Lira ${ }^{1}$, Lucas E Nascimento ${ }^{1}$, Maria VO Santos ${ }^{1}$, Moacir F

5 Oliveira $^{2}$, Alexandre R Silva ${ }^{3}$, Alexsandra F Pereira ${ }^{1}$

$7{ }^{1}$ Laboratory of Animal Biotechnology, Federal Rural University of Semi-Arid, Rio Grande do

8 Norte/Mossoró, Brazil

9 22Laboratory of Applied Animal Morphophysiology, Federal Rural University of Semi-Arid, Rio

10 Grande do Norte/Mossoró, Brazil

11 '3aboratory of Animal Germplasm Conservation, Federal Rural University of Semi-Arid, Rio

12 Grande do Norte/Mossoró, Brazil

15 Corresponding Author:

16 Alexsandra F Pereira ${ }^{1}$

17 Av. Francisco Mota, 572, Mossoro/RN, 59625 900, Brazil

18 Phone: +558433178361

19 E-mail address: alexsandra.pereira@ufersa.edu.br

21 Running title: Peccary skin-derived fibroblast lines. 


\section{Abstract}

24 Background. Biobanking of cell lines is a promising tool of support for wildlife conservation. In particular, the ability to preserve fibroblast cell lines derived from collared peccaries is of significance as these wild mammals are unique to the Americas and play a large role in maintaining the ecosystem. We identified collared peccary fibroblasts by immunofluorescence and evaluated their morphology, growth, and adherence capacity. Further, we monitored the viability and metabolic activity of the fibroblasts to determine the effects of passage number and cryopreservation on establishment of cell lines.

Methods. Skin biopsies were collected from the peripheral ear region from five adult animals in captivity. Initially, cells were isolated from fragments and cultured in the Dulbecco's modified Eagle medium (DMEM) supplemented with 10\% fetal bovine serum and 2\% antibioticantimycotic solution under a controlled atmosphere $\left(38.5^{\circ} \mathrm{C}, 5 \% \mathrm{CO}_{2}\right)$. We evaluated the maintenance of primary cells for morphology, adherence capacity of explants, explants in subconfluence, cell growth, and absence of contamination. Moreover, we identified the fibroblast cells by immunofluorescence. Additionally, to evaluate the influence of the number of passages (first, third, and tenth passage) and cryopreservation on establishment of cell lines, fibroblasts were analysed for the viability, metabolic activity, population doubling time (PDT), levels of reactive oxygen species (ROS), and mitochondrial membrane potential $(\Delta \Psi \mathrm{m})$.

Results. All explants (20/20) adhered to the dish in 2.4 days \pm 0.5 with growth around the explants in 4.6 days \pm 0.7 , and subconfluence was observed within 7.8 days \pm 1.0 . Moreover, by morphology and immunocytochemistry analyses, cells were identified as fibroblasts presenting 
46 oval nuclei, a fusiform shape, and positive vimentin staining. No contamination was observed

47 after culture without antibiotics and antifungals for 30 days. While no difference was observed

48 for cell viability after the passages (first vs. third: $\mathrm{P}=0.98$; first vs. tenth: $\mathrm{P}=0.76$; third vs.

49 tenth: $\mathrm{P}=0.85)$, metabolic activity was found to be reduced in the tenth passage $(23.2 \% \pm$

$5012.1 \%)$, when compared to that in the first and third passage $(100.0 \% \pm 24.4 \%, P=0.006)$.

51 Moreover, the cryopreservation did not influence the viability $(\mathrm{P}=0.11)$, metabolic activity $(\mathrm{P}=$

52 0.77), or PDT $(\mathrm{P}=0.11)$. Nevertheless, a greater $\Delta \Psi \mathrm{m}(\mathrm{P}=0.0001)$ was observed for the

53 cryopreserved cells $(2.12 \pm 0.14)$ when compared to that in the non-cryopreserved cells $(1.00 \pm$

54 0.05). Additionally, the cryopreserved cells showed greater levels of intracellular ROS after

55 thawing $(1.69 \pm 0.38$ vs. $1.00 \pm 0.22, \mathrm{P}=0.04)$.

56

57 Conclusions. This study is the first report on isolation, characterization, and cryopreservation of

58 fibroblasts from collared peccaries. We showed that adherent cultures were efficient for

59 obtaining fibroblasts, which can be used as donor cells for nuclei for species cloning and other

60 applications.

61

62 Subjects: Cell Biology, Veterinary Medicine.

63 Keywords: Biological characterization, cellular conservation, cryobanking, wild mammals.

64

65 Introduction

66 Collared peccaries (Pecari tajacu Linnaeus, 1758) are wild mammals found only in the Americas

67 and show a distribution from southern United States to northern Argentina, inhabiting the most

68 diverse environments (Santos et al., 2009). Currently, their population is considered to be stable 
69 (Gongora et al., 2011); however, a significant reduction of their population has been seen in 70 some biomes, such as the Caatinga (Desbiez et al., 2012) and the Atlantic forest (Lazure et al., 71 2010). As excellent seed dispersers (Redford 1992), they are very important for the maintenance 72 of our ecosystem, whereas, economically, they have been commercialized for their meat and in 73 leather production (Santos et al., 2009). Scientifically, collared peccaries can be used as

74 experimental models for closely related species such as the Tayassu peccary and Catagonus 75 wagneri that have been listed as "vulnerable" in the IUCN Red List of Threatened Species 76 (Keuroghlian et al., 2013; Altrichter et al., 2015).

78 In this sense, studies related to the conservation of the collared peccary have been intensified, 79 especially aimed at improving the techniques related to the preservation of somatic samples. 80 Using this study, we established a culture condition for explants derived from the skin of adult 81 collared peccaries (Santos et al., 2016) and developed a protocol for cryopreservation (Borges et 82 al., 2017; Borges et al., 2018a; Borges et al., 2018b) and refrigeration of these explants (Queiroz 83 Neta et al., 2018). In order to conduct the cloning experiments on this species by a somatic cell 84 nuclear transfer, as well as to produce induced pluripotent cells, it is necessary to establish 85 properly characterized cell lines.

87 In general, as observed in other mammals (Guan et al., 2010; Kwong et al., 2014), establishment 88 of an adequate cell line is a prerequisite step for the success of cloning and producing induced 89 pluripotent cells (Borges \& Pereira 2019). For these techniques, fibroblasts and epithelial cells 90 derived from the skin have been widely used (Jyotsana et al., 2016; Siengdee et al., 2018).

91 Initially, epithelial and fibroblast cells were grown simultaneously; nevertheless, fibroblasts can 
92 more easily adhere as well as detach by trypsinization as compared to the epithelial cells (Bai et 93 al., 2012; Saadeldin et al., 2019; Siengdee et al., 2018). In these methods, the culture after the

94 second passage has been considered to contain mainly fibroblasts (Mehrabani et al., 2014).

95

Additionally, for the confirmation of a fibroblast line, it is necessary to verify the possible

97

98 induced pluripotent cells.

112 Materials \& Methods changes that occur in these cells during culture (Guan et al., 2010; Song et al., 2007) and cryopreservation (Magalhães et al., 2017). In general, the number of passages throughout an in vitro study can modify the cellular epigenetic state, affecting the embryonic development after cloning (Rodriguez-Osorio et al., 2012; Trokovic et al., 2015). Magalhães et al. (2017) observed a reduced viability and metabolic activity in the cells derived from the skin of the brown brocket deer in the tenth passage. Thus, the establishment of a cell line ensures a complete knowledge of the parameters that confer quality to the nucleus of the donor cell, named the karyoplast (Guan et al., 2010). Moreover, identification of the damages occurring during cryopreservation is essential for establishment of a cell line. Cryo-variables may affect several cellular processes, including survival, functionality, and the cytoskeleton, which may compromise the reprogramming ability of the karyoplasts (Chatterjee et al., 2017). Therefore, we aimed to isolate, characterize, and cryopreserve the fibroblast cells derived from the skin of the ear of collared peccaries for their future application in cloning strategies by a somatic cell nuclear transfer and production of

Chemicals and media 
114 The Dulbecco's modified Eagle medium (DMEM), fetal bovine serum (FBS), penicillin,

115 streptomycin, and amphotericin solutions were obtained from Gibco-BRL (Carlsbad, USA).

116 Fluorescent probes were purchased from Invitrogen (Carlsbad, USA). Anti-vimentin antibody

117 and goat anti-mouse IgG (Alexa Fluor ${ }^{\circledR} 488$ ) were purchased from Abcam (Cambridge, USA).

118 The other chemicals were obtained from Sigma-Aldrich (St. Louis, USA). Media were filtered

119 using a $0.22-\mu \mathrm{m}$ system (Corning, New York, USA) and adjusted to $\mathrm{pH}$ of 7.2-7.4.

120

121 Bioethics and animals

122 This study was approved by the Ethics Committee of Animal Use of the Federal Rural

123 University of Semi-Arid (CEUA/UFERSA, no. 23091.001072/2015-92) and the Chico Mendes

124 Institute for Biodiversity Conservation (ICMBio, no. 48633-2). All animals belonged to the

125 Centre of Multiplication of Wild Animals (CEMAS/UFERSA, Mossoró, RN, Brazil, 5¹0’S,

$\left.12637^{\circ} 10^{\prime} \mathrm{W}\right)$, registered at the Brazilian Institute of Environment and Renewable Natural Resources

127 (IBAMA) as a scientific breeding site (no. 1478912). The breeder stocks 100 collared peccaries

128 on an average, and for this research four females and one male at ages of 26.8 months \pm 2.9

129 months were used.

130

131 Ear tissue explant collection and primary culture

132 Peripheral skin $\left(1 \mathrm{~cm}^{2}-2 \mathrm{~cm}^{2}\right)$ was recovered from the ear sections used to identify collared

133 peccaries kept in captivity. After the collection, a trichotomy of the tissue followed by a

134 sterilization with $70 \%$ alcohol was performed. Samples were transported to the laboratory in

135 DMEM supplemented with $2 \%$ antibiotic-antimycotic solution $(10,000$ units/mL penicillin,

$13610,000 \mu \mathrm{g} / \mathrm{mL}$ streptomycin, and $25 \mu \mathrm{g} / \mathrm{mL}$ amphotericin B) at $37^{\circ} \mathrm{C}$ within $30 \mathrm{~min}$. 
138 In the laboratory, fragments $\left(9.0 \mathrm{~mm}^{3}\right)$ were washed sequentially under laminar flow in the 139 following media: 1) DMEM supplemented with 10\% FBS, and 10\% antibiotic-antimycotic 140 solution; 2) alcohol; and 3) DMEM plus 10\% FBS, and 2\% antibiotic-antimycotic solution. 141 Then, the samples were fragmented (four fragments per animal) and placed in polystyrene

142 culture dishes treated for cell adhesion with the latter medium for cell culture. The skin was 143 cultured at $38.5^{\circ} \mathrm{C}$ under a controlled environment with $5 \% \mathrm{CO}_{2}$ and $95 \%$ air, according to a 144 method described by Santos et al. (2016).

Evaluation of the somatic cells in primary cultures and subcultures

147 During primary culture, the medium was changed every $24 \mathrm{~h}$. For evaluation of the somatic cells,

148 the primary culture was analyzed before reaching confluency and until it reached a confluency of $14970 \%-80 \%$. Using an inverted microscope (Nikon TS100, Tokyo, Japan), the cells were evaluated 150 for the following parameters: cell morphology, number of adhered samples, number of samples, 151 evident subconfluency, day of sample adherence, day of subconfluent growth of the samples, and 152 total time to reach $70 \%-80 \%$ confluence (Borges et al., 2017).

154 When the cells reached $70 \%-80 \%$ subconfluency, they were subcultured and distributed for 155 other analyses. The $70 \%-80 \%$ subconfluence was defined as the stage when $70 \%-80 \%$ of the 156 culture dishes consisted of somatic cells (Santos et al., 2016). Subconfluent cells were washed 157 with PBS then trypsinized with a trypsin/EDTA solution $(0.25 \% / 0.2 \%)$ for 7 min and centrifuged 158 at $600 \mathrm{x} g$ for $10 \mathrm{~min}$. The supernatant was removed, the cell pellet was resuspended in culture 159 medium, and the cell suspension was transferred to another dish for subculturing (Borges et al., 
$1602018 b$ ). The medium was replaced with a fresh medium every other day and the cells were

161 monitored daily. With the successful passaging of the cultures, the cells are considered a cell

162 line, following the convention of the Society of In Vitro Biology (Schaeffer, 1990). The cell line 163 was designated as Ptskf.

164

165 Thus, in addition to an evaluation of the maintenance of cells in the primary culture, the 166 subcultured cells were initially evaluated for the confirmation of fibroblasts using morphology 167 and immunofluorescence analyses. Moreover, the possibility of contamination was also 168 evaluated. Subsequently, the influence of the number of passages (first, third, and tenth passage) 169 and the metabolic activity of the cells were analyzed by a viability assay using trypan blue and 170 the 3-(4, 5-dimethylthiazolyl-2)-2, 5-diphenyltetrazolium bromide (MTT) assay, respectively. 171 Moreover, the cells were also evaluated for the effects of a slow freezing cryopreservation. Other 172 than the above-mentioned tests, growth dynamics by quantification of the population doubling 173 time (PDT), oxidative stress analysis for quantification of intracellular reactive oxygen species 174 (ROS) levels using the fluorescent probe 2',7'-dichlorodihydrofluorescein diacetate $\left(\mathrm{H}_{2} \mathrm{DCFDA}\right)$, 175 and assessment of the mitochondrial membrane potential $(\Delta \Psi \mathrm{m})$ using the fluorescent probe 176 MitoTrackerRed $®$ were performed.

177

178 Morphological characterization of the fibroblasts

179 Morphological characteristics were observed throughout the in vitro culture under light 180 microscopy for cellular and nuclear shapes and cytoplasmic extensions. 181

Vimentin immunofluorescence 
183 For a morphological confirmation, the cells were subjected to an immunocytochemistry protocol

184 based on the method described by Amoli et al. (2017). Briefly, the cells were fixed using 4\%

185 paraformaldehyde for $10 \mathrm{~min}$ at $25^{\circ} \mathrm{C}$, then washed with chilled PBS. Subsequently, cells were

186 incubated with an antigen-retrieval buffer (100 mM Tris, 5\% urea, $\mathrm{pH} 9.5)$, and then

187 permeabilized for $1 \mathrm{~h}$ in $0.4 \%$ Triton $\mathrm{X}-100$. Afterwards, the cells were incubated in $0.1 \%$

188 Tween-20 for $1 \mathrm{~h}$ to block non-specific binding of the antibodies. Finally, the cells were

189 immuno-stained with mouse anti-vimentin antibody (ab8979, 1:200) for $24 \mathrm{~h}$ at $4^{\circ} \mathrm{C}$, and, then

190 incubated with the secondary antibody (goat anti-mouse IgG, Alexa Fluor ${ }^{\circledR}$ 488, ab150113,

191 1:400) for $1 \mathrm{~h}$ at $25^{\circ} \mathrm{C}$ in the dark. Cells were counter-marked with $1 \mu \mathrm{g} / \mathrm{mL}$ Hoechst for $1 \mathrm{~min}$

192 and observed under a fluorescence microscope (Olympus BX51TF, Tokyo, Japan).

193

194 Confirmation of the absence of bacterial and fungal contamination

195 Cells of the third passage were cultured for 30 days in DMEM containing $10 \%$ FBS in the

196 absence of an antibiotic-antimycotic solution, at $38.5^{\circ} \mathrm{C}, 5 \% \mathrm{CO}_{2}$ and $95 \%$ air. Daily evaluation

197 was performed under light microscopy for the identification of bacterial and fungal

198 contamination.

199

200 Influence of the passage number on the quality of fibroblast lines

201 Initially, the fibroblast cells were analyzed for the effect of the number of passages (first, third,

202 and tenth passage) by a viability assay using trypan blue, according to the method described by

203 Magalhães et al. (2017). We evaluated these three cell passages specifically because both

204 fibroblast and epithelial cells were present in the initial (first) passage, only fibroblasts were

205 visualized at the third passage onwards, and the cells of the tenth passage were used for most of 
206 the production of embryonic clones (Shiga et al., 1999; Kubota et al., 2000). The evaluations

207 were performed in triplicate for each animal for each passage.

208

209 Briefly, the cells were stained with 0.4\% trypan blue in PBS and counted on a hemocytometer.

210 Subsequently, the cells were also analyzed for a metabolic activity using the MTT assay,

211 according to the method described by Borges et al. (2018b). A concentration of $5.0 \times 10^{4}$

212 cells $/ \mathrm{mL}$ from the first, third, and tenth passages was grown in 12-well polystyrene plates treated

213 for cell adhesion. After 5 days, $1.5 \mathrm{~mL}$ of the MTT solution ( $5 \mathrm{mg} / \mathrm{mL}$ in DMEM) was added

214 and the polystyrene culture dishes treated for cell adhesion were incubated for $3 \mathrm{~h}$. The MTT

215 solution was then removed and $1.0 \mathrm{~mL}$ of dimethyl sulfoxide (DMSO) was added for $5 \mathrm{~min}$

216 under slow stirring to solubilize the MTT. After the total dissolution of formazan crystals,

217 samples were analyzed in a spectrophotometer (Shimadzu ${ }^{\circledR}$ UV-mini-1240, Kyoto, Japan) at an

218 absorbance wavelength of $595 \mathrm{~nm}$. The evaluations were performed in triplicate for each animal

219 for each passage.

220

221 Influence of cryopreservation on the quality of fibroblast lines

222 To evaluate the effect of cryopreservation on the quality of fibroblast lines, cells of the third

223 passage of the five animals were subjected to slow freezing in the freezing medium (DMEM

224 supplemented with 10\% DMSO as a permeating cryoprotectant and 50\% FBS and $0.2 \mathrm{M}$ sucrose

225 as non-permeating cryoprotectants). Cells at a concentration of $5.0 \times 10^{4}$ cells $/ \mathrm{mL}$ were first

226 exposed to DMSO-FBS solution for $15 \mathrm{~min}$ at $4^{\circ} \mathrm{C}$, then sucrose solution was added followed by

227 an additional incubation for $15 \mathrm{~min}$ at $4^{\circ} \mathrm{C}$. The cryovials containing $1.0 \mathrm{~mL}$ of cells in the

228 freezing medium were cooled in a Mr. Frosty freezing container (Thermo Scientific, Waltham, 
229 USA) at a cooling rate of $1{ }^{\circ} \mathrm{C} / \mathrm{min}$, and later stored in a freezer at $-80^{\circ} \mathrm{C}$, reaching $-70^{\circ} \mathrm{C}$

230 overnight before being transferred into liquid nitrogen (León-Quinto et al., 2014).

231

232 For thawing, the cryovials were exposed for $1 \mathrm{~min}$ at $25^{\circ} \mathrm{C}$ and immersed in a water bath at $37^{\circ} \mathrm{C}$ 233 for $3 \mathrm{~min}-4 \mathrm{~min}$. Then, the cell contents were removed from the cryovials and washed to remove 234 the cryoprotectants. Initially, the first wash was performed with DMEM and 10\% FBS 235 containing $0.2 \mathrm{M}$ sucrose at $4^{\circ} \mathrm{C}$ for $15 \mathrm{~min}$ and centrifuged. Subsequently, the second wash was 236 performed using only DMEM and $10 \% \mathrm{FBS}$, maintained at $25^{\circ} \mathrm{C}$ for $15 \mathrm{~min}$, centrifuged, and the 237 cells were recovered for the evaluations as per a method described previously (Santos et al., 238 2016).

239

240 After thawing, the non-cryopreserved and the cryopreserved cells were evaluated for growth

241 dynamics by quantification of PDT. The evaluations were performed in triplicate for each

242 animal. Briefly, the growth kinetics was studied for nine days using $3.0 \times 10^{4}$ cells $/ \mathrm{mL}$, and cells

243 were counted daily to determine the number of growing cells. Data on the cell growth and

244 density were monitored and recorded, mean values of which were used to plot a growth curve 245 and calculate PDT (Roth 2006) using the following formula:

$246 \mathrm{PDT}=\mathrm{T} \ln 2 / \ln (\mathrm{Xe} / \mathrm{Xb})$ where PDT is the time of the culture (in hours), $\mathrm{T}$ is the incubation time, $247 \mathrm{Xb}$ is the number of cells at the beginning of the time incubation, $\mathrm{Xe}$ is the number of cells at the 248 end of the incubation time, and $\ln$ is the Napierian logarithm.

250 Moreover, for evaluation of an oxidative stress by quantification of the intracellular ROS levels, 251 cells were stained with the fluorescent probe $\mathrm{H}_{2}$ DCFDA, according to a method described by 
252 Santos et al. (2019). Thawed cells were washed with PBS and placed into polystyrene culture

253 dishes treated for cell adhesion containing $500 \mu \mathrm{L}$ of $5 \mu \mathrm{M} \mathrm{H}_{2}$ DCFDA. The cells obtained after a

$25470 \%$ confluency were incubated at $38.5^{\circ} \mathrm{C}$ in $5 \% \mathrm{CO}_{2}$ for $30 \mathrm{~min}$. Stained cells were washed

255 with PBS, placed on glass slides, photographed under a fluorescence microscope (Olympus

256 BX51TF, Tokyo, Japan), and fluorescence signal intensity (pixels) was quantified. Ten images

257 (two/animal) obtained were evaluated using the ImageJ software (version 1.49v, Java 1.8.0_201,

258 Wayen Rasband, U.S. National Institutes of Health, Bethesda, MD, USA; website:

259 http://rsb.info.nih.gov/ij/download.html). The background signal intensity was subtracted from

260 the values obtained for the treated samples. Measured mean value of the micrograph for the non-

261 cryopreserved cells was taken as a calibrator. Relative expression levels (arbitrary fluorescence

262 units) were generated by dividing the measured value of each micrograph for the cryopreserved

263 cells by the mean of the calibrator.

264

265 Finally, for the assessment of $\Delta \Psi \mathrm{m}$, cells were stained using $500 \mathrm{nM}$ of the fluorescent probe

266 MitoTracker Red ${ }^{2}$ (CMXRos), according to a method described by Santos et al. (2019). The

267 procedure, incubation, and evaluation of the ten images (two/animal) were performed as

268 described for the quantification of ROS.

269

270 Statistical analysis

271 All data have been expressed as the mean \pm standard error (one animal/one repetition) and were

272 analyzed using the StatView 5.0 software (Graph-Pad Software Incorporation, La Jolla, USA).

273 Normality of all results was verified by the Shapiro-Wilk test and homoscedasticity was verified

274 by the Levene's test. ROS levels, $\Delta \Psi \mathrm{m}$, viability, and metabolic activity were altered with 
275 arcsine and analysed by variance analysis (ANOVA) followed by the Tukey's test. PDT was

276

$277 \quad 0.05$

278

\section{Results}

280

281

282

283

284

285

286 $287 \pm 1.0$ day), were different.

288

289

290

291

292

293

294

295

296

297 replaced the epithelial cells.

\section{Vimentin immunofluorescence}

Evaluation of the somatic cells in the primary cultures and subcultures

The total culture time was 95 days with an evaluation of cells until the tenth passage. The adhesion of the fragments (Fig. 1A), detachment of cells (Fig. 1B-1C), and proliferative capacity were observed in all the explants until reaching a confluence (and later, a subconfluence) around the adhered fragments (Fig. 1D-1F, Table 1). All explants had adhesion ability and reached subconfluence. Number of days for each explant to reach a $100 \%$ tissue adherence $(2.4$ days \pm 0.5 days), to grow around the explants (4.6 days \pm 0.7 day), and to reach subconfluence ( 7.8 days

Morphological characterization of the fibroblasts

In cultures, monolayers of cells with a fibroblast-like morphology were observed (Fig. 1E). The cells had an oval nuclei and extensions with a fusiform shape, showing rapid growth that

Morphology of the fibroblast-like cells in the initial culture was observed by light microscopy, which was further confirmed for the cell type identification as vimentin-labeled fibroblasts under fluorescence microscopy (Fig. 2A-2F). Cells exhibited a high expression of vimentin that marked 
298 the cytoplasm completely, and the spindle-like shape and ovoid nucleus was highlighted by the

299 Hoechst labeling. Therefore, the identification of a fibroblast cell was evident.

300

301 Confirmation of the absence of bacterial and fungal contamination

302 No sign of contamination (turbidity, colony, or hyphal growth) was observed for 30 days in the

303 culture without antibiotics and antifungals. The culture medium did not show any change in the

304 appearance when observed under a light microscope. We did not observe turbidity or any

305 specific odor. In addition, there was no change in the biological characteristics of growth and

306 proliferation indicating a complete absence of contamination.

307

308 Influence of the passage number on the quality of fibroblast lines

309 No significant difference was observed in the cell viability ( $74.5 \%$ to $84.4 \%$ ) when evaluated by

310 trypan blue staining after the passages (first vs. third: $\mathrm{P}=0.98$; first vs. tenth: $\mathrm{P}=0.76$; third vs.

311 tenth: $\mathrm{P}=0.85)$. However, the metabolic activity was reduced in the tenth passage $(23.2 \% \pm$

$31212.1 \%)$ as compared to that of the first and third passages $(100.0 \% \pm 24.4 \%, \mathrm{P}=0.006)$.

313

314 Influence of cryopreservation on the quality of fibroblast lines

315 Cryopreservation did not affect the viability when evaluated by trypan blue staining $(87.4 \% \pm$

$3160.3 \%$ vs. $74.0 \% \pm 5.9 \%, \mathrm{P}=0.11$ ). Moreover, after two passages of the thawed cells, the viability

317 was $86.4 \% \pm 3.2 \%$. In addition, no difference $(\mathrm{P}=0.77)$ was observed for the metabolic activity

318 between the cryopreserved $(85.2 \% \pm 10.0 \%)$ and the non-cryopreserved cells $(100.0 \% \pm 36.4 \%)$. 
320 Moreover, the cryopreserved and the non-cryopreserved cells were compared for growth

321 dynamics (Fig. 3). The growth curve of both groups showed a typical "S-shaped" pattern from

322 the nine-day culture of cells. The latency time was two days, followed by an exponential phase

323 until the fourth day, the stationary phase until the seventh day, and the plateau phase from day

324 eight (Fig. 3A). No difference was observed for the PDT values of the cryopreserved and the

325 non-cryopreserved cells $(\mathrm{P}=0.11$, Fig. $3 \mathrm{~B})$.

326

327 Nevertheless, the cryopreserved cells showed greater levels of intracellular ROS (Fig. 4A) in

328 arbitrary fluorescence units when compared to that of the non-cryopreserved cells $(1.69 \pm 0.38$

329 vs. $1.00 \pm 0.22, \mathrm{P}=0.04$ ) (Fig. $4 \mathrm{C}$ ). In addition, an alteration in the $\Delta \Psi \mathrm{m}$ (Fig. 4B) in arbitrary

330 fluorescence units $(\mathrm{P}=0.0001)$ was observed for the cryopreserved cells $(2.37 \pm 0.07)$ when

331 compared to that of the non-cryopreserved cells (1.00 \pm 0.05$)$ (Fig.4D).

332

333 Discussion

334 In this study, we isolated, characterized, and cryopreserved the fibroblast cells derived from the 335 skin of collared peccaries. Moreover, we established the fibroblast cell lines of these animals 336 with an aim to use these cells in cloning experiments by a somatic cell nuclear transfer in the 337 future. The cell line can be considered as the first constituent of the peccary invitrome and a 338 resource for future studies in many disciplines (Barioch 2018; Bols et al., 2017). Thus, the ear

339 tissues of collared peccaries can be isolated and grown into fibroblasts in an adherent culture for

340 establishment of cell lines and development of a cryobank. The development of these somatic

341 cell banks has been increasing in the interest of conserving genetic samples of wild mammals to 
342 preserve valuable species, and as sources for biological research (León-Quinto et al., 2009;

343 Mehrabani et al., 2014; Saadeldin et al., 2019; Siengdee et al., 2018).

344

345 All explants adhered to the flask surface within 2 days to 4 days, with cellular growth around the 346 explant within 3 days, and demonstrating confluency within 5 days to 10 days after a culture

347 initiation. These characteristics of explants during in vitro culture were similar to the explants

348 derived from other domestic and wild mammals. In studies using tissues from horses, the

349 migration of fibroblast and epithelial-like cells from explants have been observed after 5 days to

3507 days of an in vitro culture (Amoli et al., 2017). In the case of goat-derived tissues, the explants

351 reportedly adhered to the flasks within 5 days to 7 days and the cells became confluent within 3

352 days to 5 days post adhesion (Bai et al., 2012). In the Iranian Sistani cattle-derived tissues, the

353 explants adhered to the culture flasks within 7 days to 14 days and were observed to allow the

354 growth of fibroblast-like cells from the margins of explants (Gorji et al., 2017).

355

356 For the Luxi cattle-derived tissues, fibroblast-like or epithelial-like cells could be seen migrating

357 from the tissues within 5 days to 12 days post adhesion (Liu et al., 2008). In the tissues derived

358 from wild camels, fibroblast-like or epithelial-like cells could be seen migrating from the sides of

359 explants within 8 days to 10 days post adhesion (Sharma et al., 2018). In tissues derived from the

360 domestic porcine, a species phylogenetically close to the collared peccaries, all the explants

361 adhered within 3 days to 8 days (Silvestre, Sánchez \& Gómez, 2004). The similarity among these

362 data can be related to the culture medium because in a majority of these studies, DMEM

363 containing FBS, antibiotic, and antimycotic solution was used (Magalhães et al., 2017;

364 Saadeldin et al., 2019; Siengdee et al., 2018). Since primary culture needs to mimic the in vivo 
365 environment of the cells (Guo et al., 2018), we observed previously (Santos et al., 2016) that the

366 medium for growth of somatic cells derived from collared peccaries was DMEM with 10\% FBS

367 and $2 \%$ antibiotic-antimycotic solution.

368

369 We showed that ear explant cultures obtained from the tissues of the collared peccaries were

370 efficient for cell recovery allowing a culture for 95 days and up to ten passages. Moreover, we

371 confirmed that the ear skin was a common source where fibroblasts cells could be separated and

372 eventually used as karyoplasts for cloning purposes (Luo et al., 2014). These cells were

373 identified by vimentin, an intermediate filament that indicates the mesenchymal origin of

374 endothelial and fibroblast cells (Yajing et al., 2018). Initially, during in vitro culture, epithelial

375 and fibroblastic cells grew simultaneously. However, fibroblasts can be trypsinized more rapidly

376 and adhere more easily as compared to the epithelial cells (Bai et al., 2012; Saadeldin et al.,

377 2019). Therefore, in this work, cells from the third passage were confirmed as fibroblasts by

378 morphology and immunofluorescence analyses.

379

380 The clear medium observed during the 30-day assay demonstrated the ability to allow the growth

381 of the culture without any biological contamination. The propagation of fungi causes turbidity by

382 accumulation of their metabolites. In addition, the colonies can be seen under a light microscope,

383 or sometimes with the naked eye (Li et al., 2007). Bacterial contamination can also be identified

384 by the naked eye as turbidity. One simple way to avoid this contamination is to filter the culture

385 medium (Bai et al., 2012). Sources of contamination may include, but are not limited to, the

386 equipment, air, culture medium, serum, and explant. Therefore, microbial contaminations are 
387 quite frequent in cell culture (Bai et al., 2012). Thus, the use of antibiotic and antimycotic

388

389

390

391

392

393

394

395

396

397

398

399

400

401

402

403

404

405

406

407

408

409

combined with careful handling, is essential to ensure the absence of contamination.

After two passages, it was possible to separate fibroblast cells from other primary cells because different cell types exhibit different cellular behavior upon trypsinization. The fibroblast cells detach quicker than epithelial cells (Gorji et al., 2017). However, fibroblasts detach in response to trypsin more rapidly than epithelial cells and adhere more quickly (Bai et al., 2012). In wild camels, the initial lag phase of $48 \mathrm{~h}$ representing the adaptation of fibroblasts and recovery from a protease damage is followed by the exponential phase (Sharma et al., 2018). In collared peccaries, the replication of cells begins to slow down after seven days because of contact inhibition, which, in wild camels, has been observed after six days (Sharma et al., 2018). No difference in the cell viability was observed among the first, third, and the tenth passage, corroborating with the studies that used cells from these passages for production of competent cloned embryos (Shiga et al., 1999; Kubota et al., 2000).

In contrast, through the metabolic activity test evaluated by the formation of formazan crystals, a significant reduction in the metabolic activity at the tenth passage was observed, indicating a reduced cellular functionality. Similar behavior was observed in cells from the brown brocket deer in which the metabolic activity measured by the MTT assay showed significantly lower values in the tenth passage than the values in the fourth passage (Magalhães et al., 2017). Therefore, the number of passages can reduce the metabolic activity rate and cell proliferation, thereby conserving cells of the early passages (Li et al., 2007). After several passages, genetic characteristics of the cells can be modified by culture conditions; hence, a minimum number of 
410 passages have been recommended to conserve the cellular characteristics (Mehrabani et al.,

411 2014). Owing to this reason, the cells were cryopreserved in the third passage for the

412 conservation of the somatic germplasm of collared peccaries.

413

414 The cell survival rate after thawing is the most commonly used criteria to evaluate the success of 415 a cryopreservation (Chatterjee et al., 2017). The cellular viability and the functional metabolic 416 activity of the cells were maintained after thawing the fibroblasts isolated from the collared 417 peccaries. This factor demonstrates that optimal in vitro culture conditions significantly influence 418 the recovery from cellular damages caused by the freezing process (Gorji et al., 2017). As for the 419 growth curve, cryopreserved cells presented a very similar profile to that of the non-

420 cryopreserved cells, showing their normal proliferation capacity regardless of the 421 cryopreservation process. The establishment of somatic cell banks using cryopreservation 422 technology is an easy and effective approach towards storing the genetic information of diverse 423 species (Li et al., 2007). However, the cells should be handled with the utmost care during 424 cryopreservation to maintain a high-quality cell bank in the long term (Mehrabani et al., 2014).

Moreover, epigenetic alterations, such as DNA fragmentation, free radical accumulation, ionic 427 imbalances, apoptosis, biochemical alterations, DNA methylation, and histone modification can 428 be a result of the cryopreservation (Chatterjee et al., 2017). These after-effects of 429 cryopreservation may have caused mitochondrial structural abnormalities, thereby promoting an 430 increased ROS production and $\mathrm{H}_{2} \mathrm{O}_{2}$ content, increased lipid peroxidation, and increased 431 expression of autophagic proteins harbored by the cells (Mata et al., 2012). A failure in the 432 mitochondrial membrane potential is a hallmark of apoptosis, leading to the collapse of the 
433 organelle and release of cytochrome-C into the cytoplasm, and ultimately activation of the 434 apoptotic cascade (Magalhães et al., 2012). Moreover, a high $\Delta \Psi \mathrm{m}$ mitochondrial respiratory 435 chain becomes a significant ROS producer (Korshunov, Skulachev, \&Starkov., 1997). Therefore, 436 a higher $\Delta \Psi \mathrm{m}$ in cryopreserved cells can be linked mainly to an increase in the oxidative stress.

438 Finally, parameters like cryovariables, including cooling and thawing rates, type and 439 concentration of the cryoprotectant, cell type and shape, and nucleation temperature may affect 440 the success of cryopreservation (Chatterjee et al., 2017). This suggests that the optimization of 441 related cryopreservation methods for the collared peccary fibroblasts to minimize an altered $442 \Delta \Psi \mathrm{m}$ and increased levels of intracellular ROS production is essential.

443

\section{Conclusions}

445 To our knowledge, this study is the very first report on a successful isolation, characterization, 446 and cryopreservation of fibroblast lines derived from adult collared peccaries (Ptskf). We 447 showed that the adherent culture was efficient for obtaining fibroblasts, which can be used as 448 donor cells for nuclei for cloning of this species. Moreover, it was possible to maintain the 449 viability of the cells until the tenth passage. In addition, cryopreservation did not affect the 450 viability, metabolic activity, and proliferative activity of the fibroblasts after slow freezing. 451 However, cryopreservation altered the ROS levels and $\Delta \Psi \mathrm{m}$, indicating necessary optimization 452 of the cryopreservation protocol. Lastly, the establishment of fibroblast cell lines derived from 453 collared peccaries may be a source of experimental models for many biological studies such as 454 nuclear reprogramming and animal cloning. 


\section{Acknowledgements}

457 The authors thank the Centre for Wild Animals Multiplication (CEMAS/UFERSA) for providing

458 the animals, and the Laboratory Biochemistry and Molecular Biology (BIOMOL/UERN) for

459 technical assistance. This study was supported by the Brazilian Council of Scientific

460 Development (CNPq) and Coordenação de Aperfeiçoamento de Pessoal de Nível Superior 461 Brasil (CAPES, Financial Code 001).

462

\section{References}

Altrichter, M., Taber, A., Noss, A., Maffei, L., Campo, J. 2015. Catagonuswagneri. The IUCN Red list of threatened species e.T4015A72587993. DOI: 10.2305/IUCN.UK.20152.RLTS.T4015A72587993.en. (accessed 07 October 2019).

467

468

469

470

471

472

473

474

475

476

477

478

\section{Amoli AD., Mohebali N., Farzaneh P., Fazeli SAS., Nikfarjam L., Movasagh SA.,} Moradmand Z., Ganjibakhsh M., Nasimian A., Izadpanah M. 2017. Establishment and characterization of Caspian horse fibroblast cell bank in Iran. In vitro Cellular \& Developmental Biology-Animal 53:337-343. DOI: 10.1007/s11626-016-0120-3.

Bai C., Wang D., Su X., Zhang M., Guan W., Ma Y. 2012. Establishment and biological research of the Jining Grey goat fibroblast line. Turkish Journal of Veterinary and Animal Sciences 36:659-667. DOI: 10.3906/vet-1106-15.

Barioch A. 2018. The Cellosaurus: a cell knowledge resource. Journal of Biomolecular Techniques 29:25-38.

Bols NC., Pham PH., Dayeh VR., Lee LEJ. 2017. Invitromatics, invitrome, and invitroomics: Introduction of three new terms for in vitro biology and illustration of their use with the cell lines from rainbow trout. In vitro Cellular \& Developmental Biology-Animal 53:383- 
479

480

481

482

483

484

485

486

487

488

489

490

491

492

493

494

495

496

497

498

499

500

501

405.DOI: $10.1007 / \mathrm{s} 11626-017-0142-5$

Borges AA., Lima GL., Queiroz Neta LB., Santos MVO., Oliveira MF., Silva AR., Pereira AF. 2017a. Conservation of somatic tissue derived from collared peccaries (Pecari tajacu Linnaeus, 1758) using direct or solid-surface vitrification techniques. Cytotechnology 69:643654. DOI: $10.1007 / \mathrm{s} 10616-017-0074-7$

Borges AA., Lira GPO., Nascimento LE., Queiroz Neta LB., Santos MVO., Oliveira MF., Silva AR., Pereira AF. 2018a. Influence of cryopreservation solution on the in vitro culture of skin tissues derived from collared peccary (Pecari tajacu Linnaeus, 1758). Biopreservation and Biobanking 16:77-81. DOI: 10.1089/bio.2017.0090.

Borges AA., Queiroz Neta LB., Santos MVO., Oliveira MF., Silva AR., Pereira AF. $2018 b$. Combination of ethylene glycol with sucrose increases survival rate after vitrification of somatic tissue of collared peccaries (Pecari tajacu Linnaeus, 1758). Pesquisa Veterinária Brasileira 38:350-356. DOI: 10.1590/1678-5150-PVB-5193.

Borges, AA., Pereira, AF. 2019. Potential role of intraspecific and interspecific cloning in the conservation of wild mammals. Zygote 27:111-117. doi: 10.1017/S0967199419000170.

Chatterjee A., Saha D., Niemann H., Gryshkov O., Glasmacher B., Hofmann N. 2017. Effects of cryopreservation on the epigenetic profile of cells. Cryobiology 74:1-7. DOI: 10.1016/j.cryobiol.2016.12.002.

Desbiez ALJ., Keuroghlian A., Mello Beisiegel B., Medici EP., Gatti A., Pontes ARM., Campos CB., Tófoli CF., Júnior EAM., Azevedo FC. 2012. Avaliação do risco de extinção do cateto Pecari tajacu Linnaeus, 1758, no Brasil. Biodiversida de Brasileira 3:74-83.

Gongora, J., Reyna-Hurtado, R., Beck, H., Taber, A., Altrichter, M., Keuroghlian, A., 2011. Pecaritajacu. The IUCN Red List of Threatened Species e.T41777A10562361. 
502 http://dx.doi.org/10.2305/IUCN.UK.20112.RLTS.T41777A10562361.en. (accessed on 26

503 May 2019).

504 Gorji ZE., Khaledi KJ., Amoli AD., Ganjibakhsh M., Nasimian A., Gohari NS., Izadpanah

505 M., Vakhshiteh F., Farghadan M., Moghanjoghi SM. 2017. Establishment and

506 characteristics of Iranian Sistani cattle fibroblast bank: a way to genetic conservation.

507 Conservation Genetics Resources 9:305-312. DOI: 10.1007/s12686-016-0640-x.

508 Guan W., Liu C., Li C., Liu D., Zhang W., Ma Y. 2010. Establishment and cryopreservation 509 of a fibroblast cell line derived from Bengal tiger (Panthera tigris tigris). Cryoletters 31:130$510 \quad 138$.

511 Guo H, Xing Y, Zhang Y, He L, Deng F, Ma X, Li Y. 2018. Establishment of an immortalized 512 mouse dermal papilla cell strain with optimized culture strategy. PeerJ 6:e4306 513 https://doi.org/10.7717/peerj.4306

514 International Union for Conservation of Nature and Natural Resources (IUCN) Red List of 515 Threatened Species.Available at http://www.iucnredlist.org/details/41777/0 (accessed 22 $516 \quad$ September 2019).

517 Jyotsana B., Sahare AA., Raja AK., Singh KP., Nala N., Singla S., Chauhan M., Manik R., 518 Palta P. 2016. Use of peripheral blood for production of buffalo (Bubalusbubalis) embryos 519 by handmade cloning. Theriogenology 86:1318-1324. DOI:

$520 \quad$ 10.1016/j.theriogenology.2016.04.073.

521 Keuroghlian, A., Desbiez, R., Reyna-Hurtado, M., Altrichter, H., Beck, A., Taber, J.M.V. 522 2013.Tayassupecari. IUCN Red List of Threatened Species 2013.1.

523 http://dx.doi.org/10.2305/IUCN.UK.2013-1.RLTS.T41778A44051115.en. (accessed 07 524 October 2019). 
525 Korshunov, SS., Skulachev, VP., Starkov, AA. 1997. High protonic potential actuates a

526 mechanism of production of reactive oxygen species in mitochondria. FEBS Lett 416:15-28.

527 doi: 10.1016/s0014-5793(97)01159-9

528 Kubota, C., Yamakuchi, H., Todoroki, J., Mizoshita, K., Tabara, N., Barber, M., Yang, X.

529 2000. Six cloned calves produced from adult fibroblast cells after long-term culture. PNAS

530 97:990-995. doi: 10.1073/pnas.97.3.990

531 Kwong P., Nam H., Wan Khadijah W., Kamarul T., Abdullah R. 2014. Comparison of in

532 vitro developmental competence of cloned caprine embryos using donor karyoplasts from

533 adult bone marrow mesenchymal stem cells vs. ear fibroblast cells. Reproduction in Domestic

534 Animals 49:249-253. DOI: 10.1111/rda.12262.

535 Lazure L., Bachand M., Ansseau C., Almeida-Cortez J. 2010. Fate of native and introduced

536 seeds consumed by captive white-lipped and collared peccaries (Tayassupecari, Link 1795

537 and Pecaritajacu, Linnaeus 1758) in the Atlantic rainforest, Brazil. Brazilian Journal of

538 Biology 70:47-53. DOI: 10.1590/S1519-69842010000100008.

539 León-Quinto T., Simón MA., Cadenas R., Martínez Á., Serna A. 2014. Different

540 cryopreservation requirements in foetal versus adult skin cells from an endangered mammal,

541 the Iberian lynx (Lynx pardinus). Cryobiology 68:227-233. DOI:

$542 \quad$ 10.1016/j.cryobiol.2014.02.001.

543 León-Quinto, T., Simón, MA., Cadenas, R., Jones, J., Martinez Hernandez, FJ., Moreno,

544 JM., Soria, B. 2009. Developing biological resource banks as a supporting tool for wildlife

545 reproduction and conservation: the Iberian lynx bank as a model for other endangered species.

546 Animal Reproduction Science 112:347-361. doi:10.1016/j.anireprosci.2008.05.070

547 Liu C., Guo Y., Guan W., Ma Y., Zhang H., Tang X. 2008. Establishment and biological 
548 characteristics of Luxi cattle fibroblast bank. Tissue and Cell 40:417-424. DOI:

$549 \quad 10.1016 /$ j.tice.2008.04.005.

550 Luo J., Liang M., Yang X., Xu H., Shi D., Lu S. 2014.Establishment and biological

551 characteristics comparison of Chinese swamp buffalo (Bubalus bubalis) fibroblast cell lines.

552 In vitro Cellular \& DevelopmentalBiology-Animal 50:7-15. DOI: 10.1007/s11626-013-9677-

5532.

554 Magalhães LC., Bhat MH., Freitas JL., Melo LM., Teixeira DI., Pinto LC., Câmara LM.,

555 Duarte JM., Freitas VJ. 2017. The effects of cryopreservation on different passages of

556 fibroblast cell culture in brown brocket deer (Mazama gouazoubira). Biopreservation and

557 Biobanking 15:463-468. DOI: 10.1089/bio.2017.0060.

558 Magalhães R., Nugraha B., Pervaiz S., Yu H., Kuleshova LL. 2012. Influence of cell culture

559 configuration on the post-cryopreservation viability of primary rat hepatocytes. Biomaterials

560 33:829-836. DOI: 10.1016/j.biomaterials.2011.10.015.

561 Mata M., Garrido-Maraver J., Cotán D., Cordero MD., Oropesa-Ávila M., Izquierdo LG.,

562 De Miguel M., Lorite JB., Infante ER., Ybot P. 2012. Recovery of MERRF fibroblasts and

563 cybrids pathophysiology by Coenzyme Q 10. Neurotherapeutics 9:446-463. DOI:

$564 \quad 10.1007 / \mathrm{s} 13311-012-0103-3$.

565 Mehrabani D., Mahboobi R., Dianatpour M., Zare S., Tamadon A., Hosseini SE.

566 2014.Establishment, culture, and characterization of Guinea pig fetal fibroblast cell.

567 Veterinary Medicine International 2014:1-5. DOI: 10.1155/2014/510328.

568 Queiroz Neta LB., Oliveira Lira GPO., Borges AA., Santos MVO., Silva MB., Oliveira

569 LRM., Silva AR., Oliveira MF., Pereira AF. 2018. Influence of storage time and nutrient

570 medium on recovery of fibroblast-like cells from refrigerated collared peccary (Pecari tajacu 
571 Linnaeus, 1758) skin. In vitro Cellular \& Developmental Biology-Animal 54:486-495. DOI:

$572 \quad 10.1007 / \mathrm{s} 11626-018-0270-6$.

573 Redford KH. 1992. The empty forest. BioScience 42:412-422.

574 Rodriguez-Osorio N., Urrego R., Cibelli J., Eilertsen K., Memili E. 2012. Reprogramming

575 mammalian somatic cells. Theriogenology 78:1869-1886. DOI:

$576 \quad$ 10.1016/j.theriogenology.2012.05.030.

577 Roth V. 2006.Available at http://www.doubling-time.com/compute.php (accessed 01 September 578 2019).

579 Saadeldin IM., Swelum AAA., Noreldin AE., Tukur HA., Abdelazim AM., Abomughaid 580 MM., Alowaimer AN. 2019. Isolation and culture of skin-derived differentiated and stem581 like cells obtained from the Arabian Camel (Camelus dromedarius). Animals 9:378-395.

582 DOI:10.3390/ani9060378

583 Santos DO., Mendes A., Nogueira SS da C., Nogueira Filho SLG. 2009. Criação comercial de 584 caititus (Pecari tajacu): uma alternativa para o agronegócio. Revista Brasileira de Saúde e 585 Produção Animal 10:1-10.

586 Santos MLT., Borges AA., Queiroz Neta LB., Santos MVO., Oliveira MF., Silva AR.,

587 Pereira AF. 2016.In vitro culture of somatic cells derived from ear tissue of collared peccary 588 (Pecaritajacu Linnaeus, 1758) in medium with different requirements. Pesquisa Veterinária $589 \quad$ Brasileira 36:1194-1202.

590 Santos, MVO., Nascimento, LE., Praxedes, EA., Borges, AA., Silva, AR., Bertini, LM., 591 Pereira, AF. 2019. Syzygiumaromaticum essential oil supplementation during in vitro bovine 592 oocyte maturation improves parthenogenetic embryonic development. Theriogenology 128 : 593 74-80. DOI:10.1016/j.theriogenology.2019.01.031 
594 Sharma R., Sharma H., Ahlawat S., Aggarwal R., Vij P., Tantia M. 2018. First attempt on 595 somatic cell cryopreservation of critically endangered Camelus bactrianus of India. Gene 596 Reports 10:109-115. DOI: 10.1016/j.genrep.2017.11.007.

597 Schaeffer WI. 1990. Terminology associated with cell, tissue and organ culture, molecular 598 biology and molecular genetics. In vitro Cellular \& Developmental Biology 26:97-101.

599 Shiga, K., Fujita, T., Hirose, K., Sasae, Y., Nagai, T. 1999. Production of calves by transfer of 600 nuclei from cultured somatic cells obtained from Japanese black bulls. Theriogenology 52: 601 527-535. DOI: 10.1016/S0093-691X(99)00149-1

602 Siengdee P., Klinhom S., Thitaram C., Nganvongpanit K. 2018. Isolation and culture of 603 primary adult skin fibroblasts from the Asian elephant (Elephas maximus). PeerJ 6:e4302. 604 DOI: $10.7717 /$ peerj.4302.

605 Silvestre MA., Sánchez JP., Gómez EA. 2004.Vitrification of goat, sheep, and cattle skin 606 samples from whole ear extirpated after death and maintained at different storage times and 607 temperatures. Cryobiology 49:221-229. DOI: 10.1016/j.cryobiol.2004.08.001.

608 Song J., Hua S., Song K., Zhang Y. 2007. Culture, characteristics and chromosome 609 complement of Siberian tiger fibroblasts for nuclear transfer. In vitro Cellular \& 610 Developmental Biology-Animal 43:203-209. DOI: 10.1007/s11626-007-9043-3.

611 Trokovic R., Weltner J., Noisa P., Raivio T., Otonkoski T. 2015. Combined negative effect of 612 donor age and time in culture on the reprogramming efficiency into induced pluripotent stem 613 cells. Stem Cell Research 15:254-262. DOI: 10.1016/j.scr.2015.06.001.

614 Yajing S., Rajput IR., Ying H., Fei Y., Sanganyado E., Ping L., Jingzhen W., Wenhua L. 615 2018. Establishment and characterization of pygmy killer whale (Feresa attenuata) dermal 616 fibroblast cell line. PloS one 13: e0195128. DOI: 10.1371/journal. pone.0195128. 
617 Table

618 Table 1 Establishment of primary culture and subcultures of somatic cells derived from 619 collared peccary ear skin.

620

\begin{tabular}{|c|c|c|c|c|c|c|}
\hline \multirow[t]{4}{*}{ Animal } & \multicolumn{3}{|c|}{ No. samples } & \multicolumn{3}{|c|}{ No. of attached samples } \\
\hline & Initial & Attached & Day all & Grow to & Day all & Subconfluence \\
\hline & & $(\%)$ & attached & subconfluence & cell grow & total time (days) \\
\hline & & & explants & $(\%)$ & explants & \\
\hline F1 & 4 & 100 & 2 & 100 & 4 & 6 \\
\hline F2 & 4 & 100 & 2 & 100 & 4 & 5 \\
\hline F3 & 4 & 100 & 1 & 100 & 3 & 9 \\
\hline F4 & 4 & 100 & 3 & 100 & 5 & 10 \\
\hline M1 & 4 & 100 & 4 & 100 & 7 & 9 \\
\hline Mean \pm & 20 & 100 & $2.4 \pm 0.5$ & 100 & $4.6 \pm 0.7$ & $7.8 \pm 1.0$ \\
\hline S.E & & & & & & \\
\hline
\end{tabular}


624 cells after the trypsinization process. Scale bar $=100 \mu \mathrm{m}$.

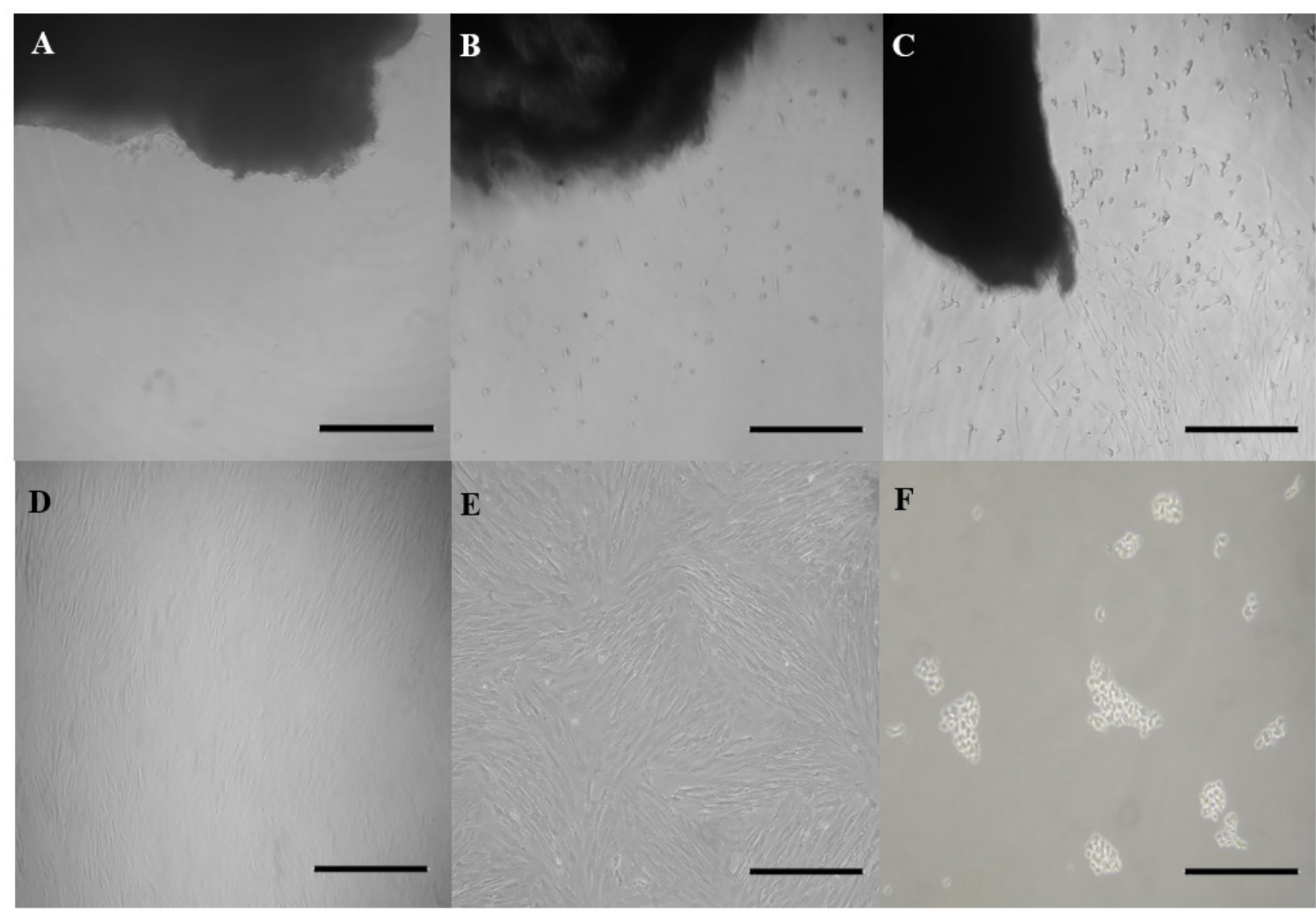




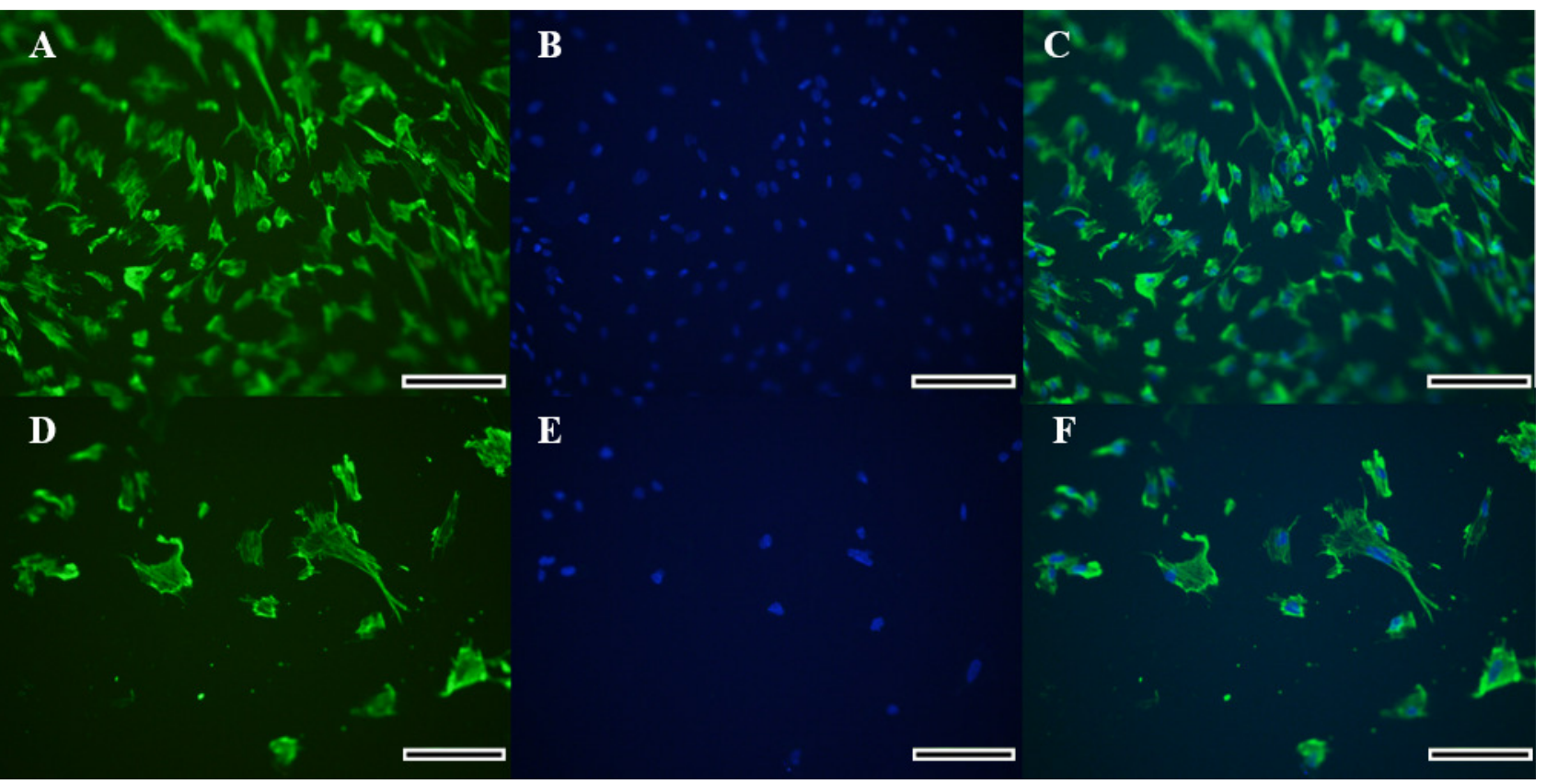




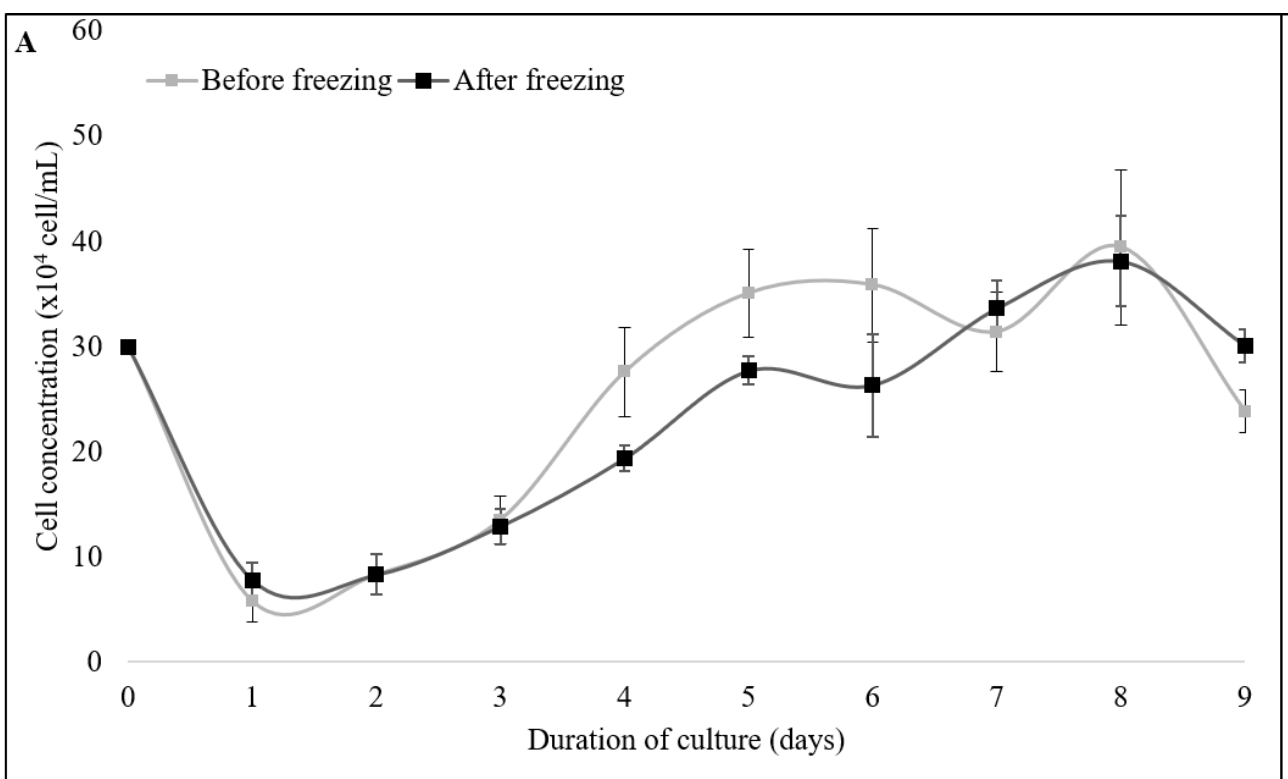

$$
\begin{aligned}
& \text { B } 300 \\
& 250
\end{aligned}
$$

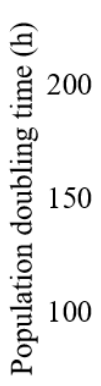

$$
\begin{aligned}
& 50 \\
& 0
\end{aligned}
$$


645 Figure 4 Evaluation of intracellular reactive oxygen species (ROS) and mitochondrial membrane potential ( $\Delta \Psi \mathrm{m})$. Cell stained 646 using fluorescent probe A) 2',7'-dichlorodihydrofluorescein diacetate ( $\mathrm{H}_{2}$ DCFDA) and B) MitoTrackerRed ${ }^{\circledR}(\mathrm{CMXRos})(\mathrm{x} 10)$.

647 Quantification of C) ROS and D) $\Delta \Psi \mathrm{m}$ levels. Scale bar $=10 \mu \mathrm{m}$. (*) Indicate statistical difference $(\mathrm{P}<0.05)$.

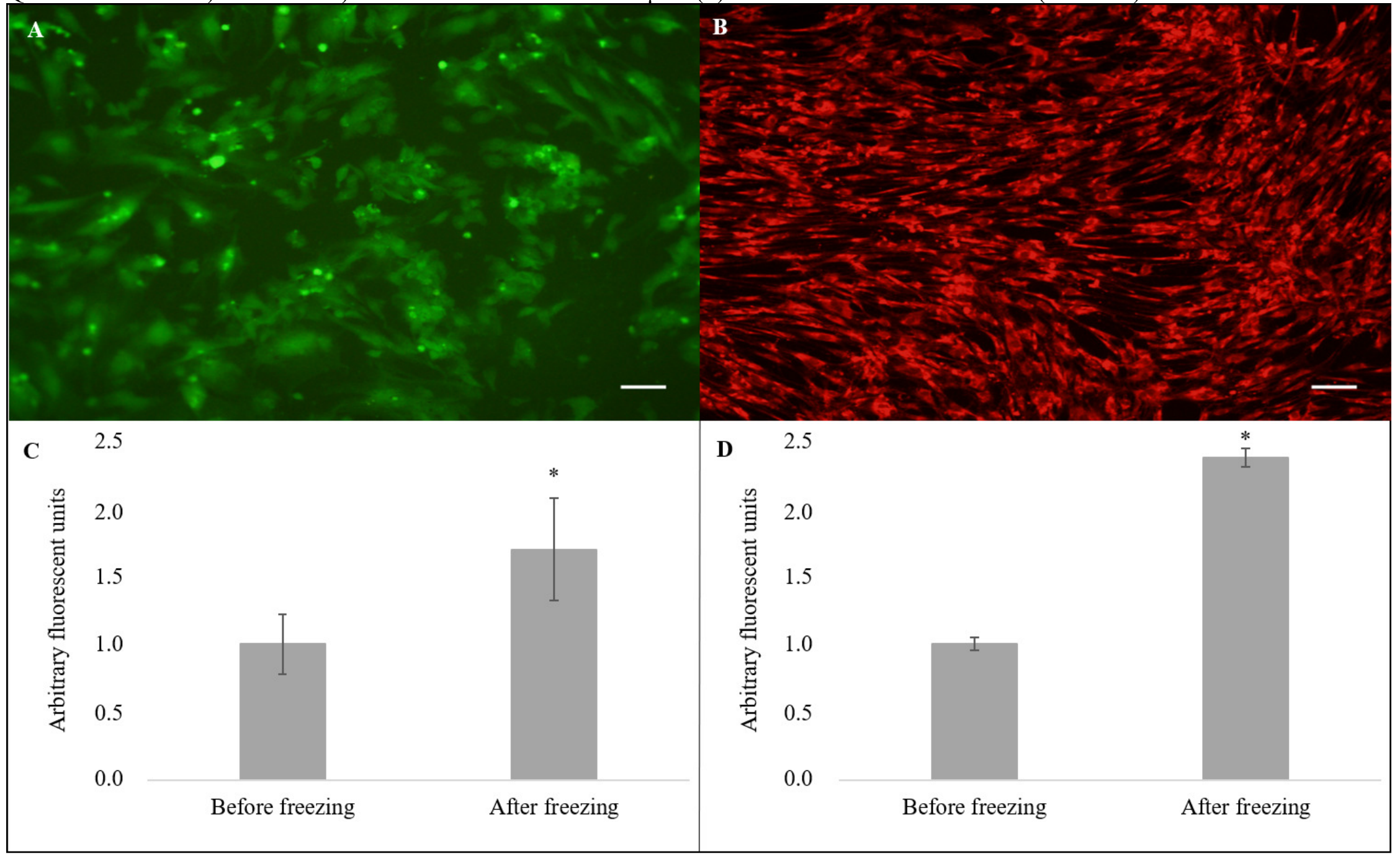




\section{Figure 1}

Outgrowth of fibroblast cells from ear skin samples of collared peccaries.

Exhibit a skin explant cultured in A) day 1, B) day 3 and C) day 5 of primary culture and exhibit a fibroblast population cultured in D) day 15 and E) day 19 of subculture. F) exhibit cells after the trypsinization process. Scale bar $=100 \mu \mathrm{m}$.

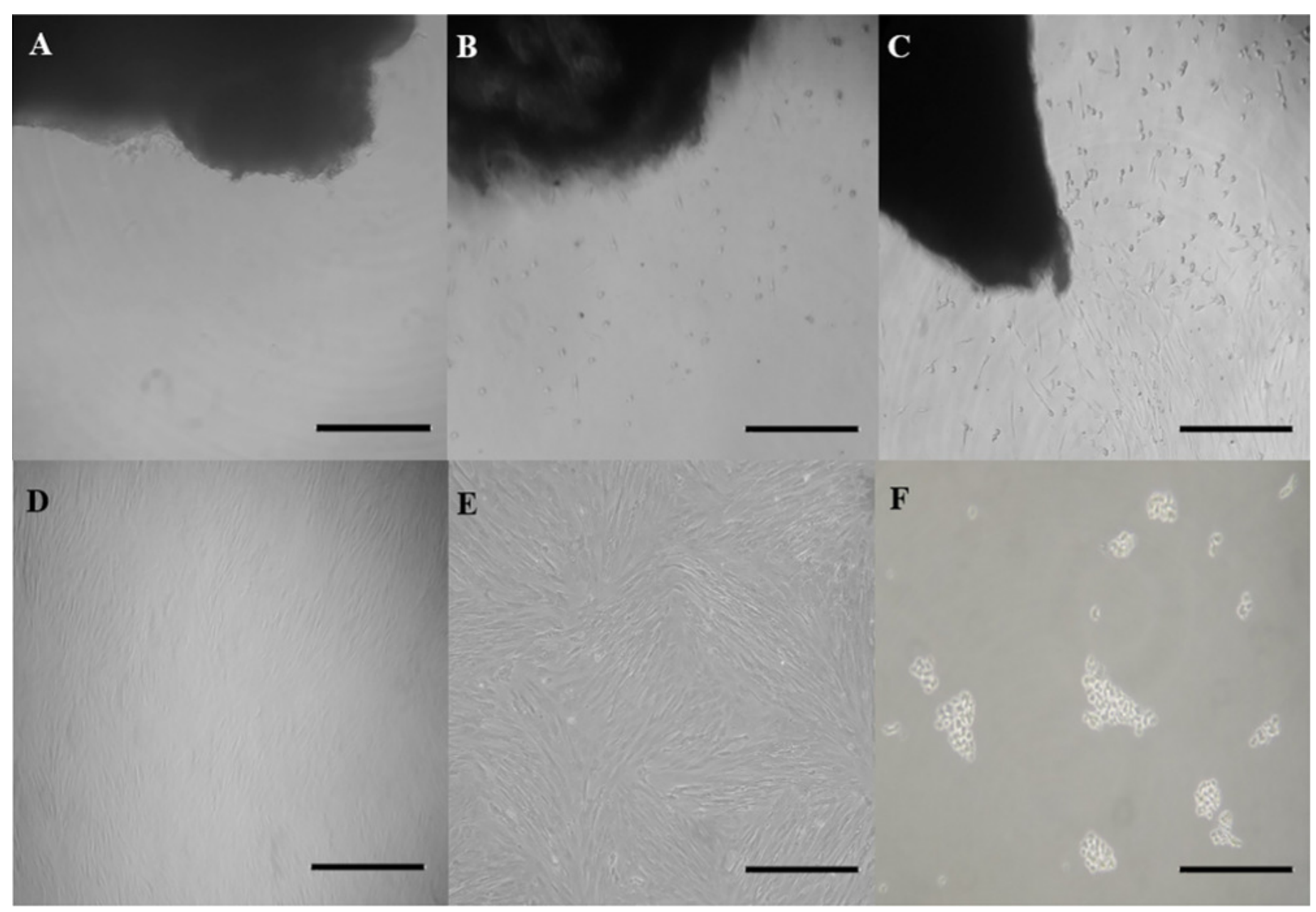




\section{Figure 2}

Immunocytochemical detection of vimetin protein for identification of collared peccary fibroblasts.

A-D) cells stained with vimetin antibody. B-E) nucleus of cells stained by Hoechst. C-F) merged vimetin (green) and Hoechst (blue). a-b-c (x5), d-e-f (x10). Scale bar $=10 \mu \mathrm{m}$.

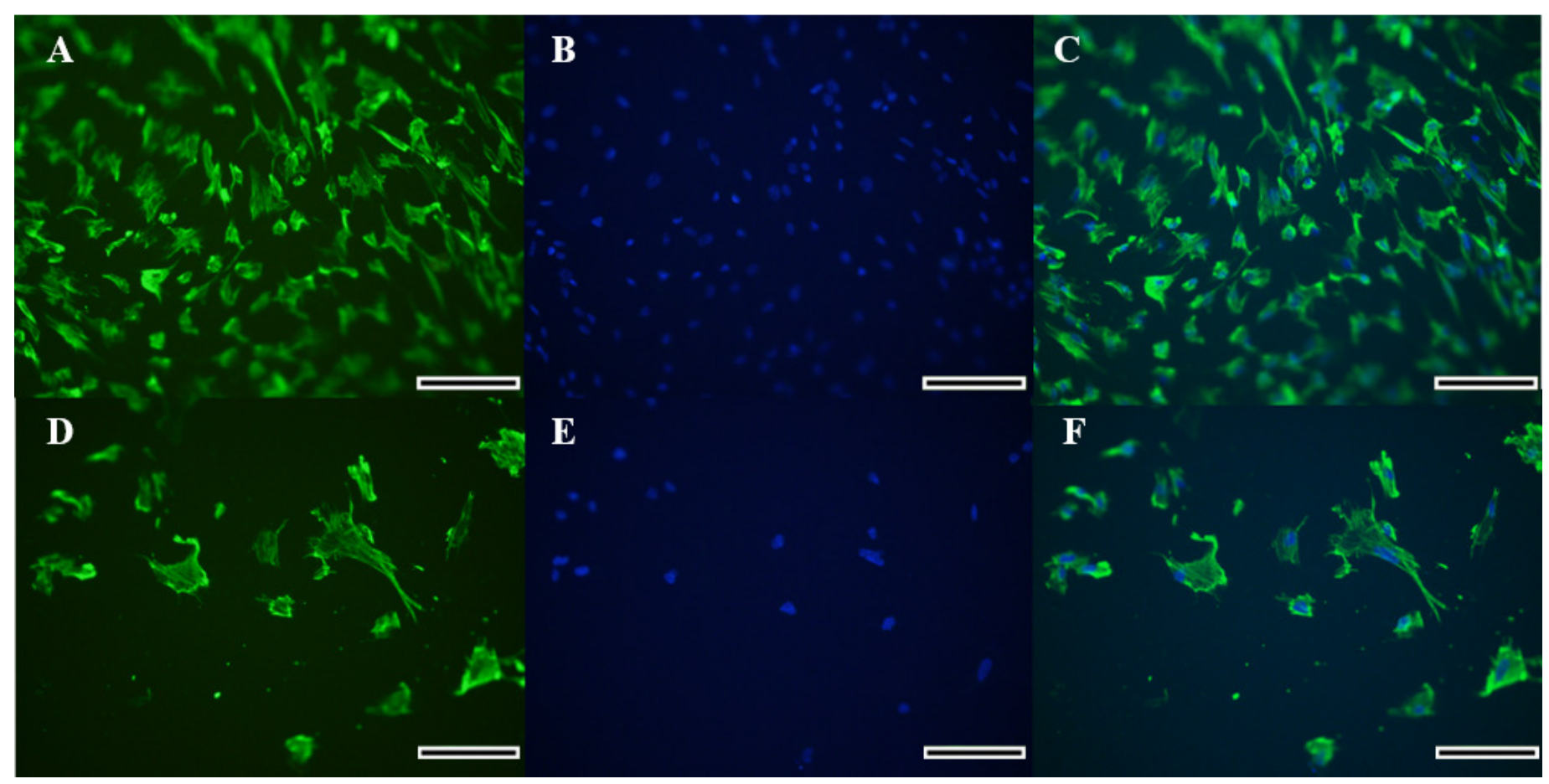


Figure 3

The growth dynamics of cryopreserved and non-cryopreserved cells derived from collared peccary skin.

A) growth curves of cryopreserved and non-cryopreserved cells. B) values of population doubling time (PDT) after culture for nine days.

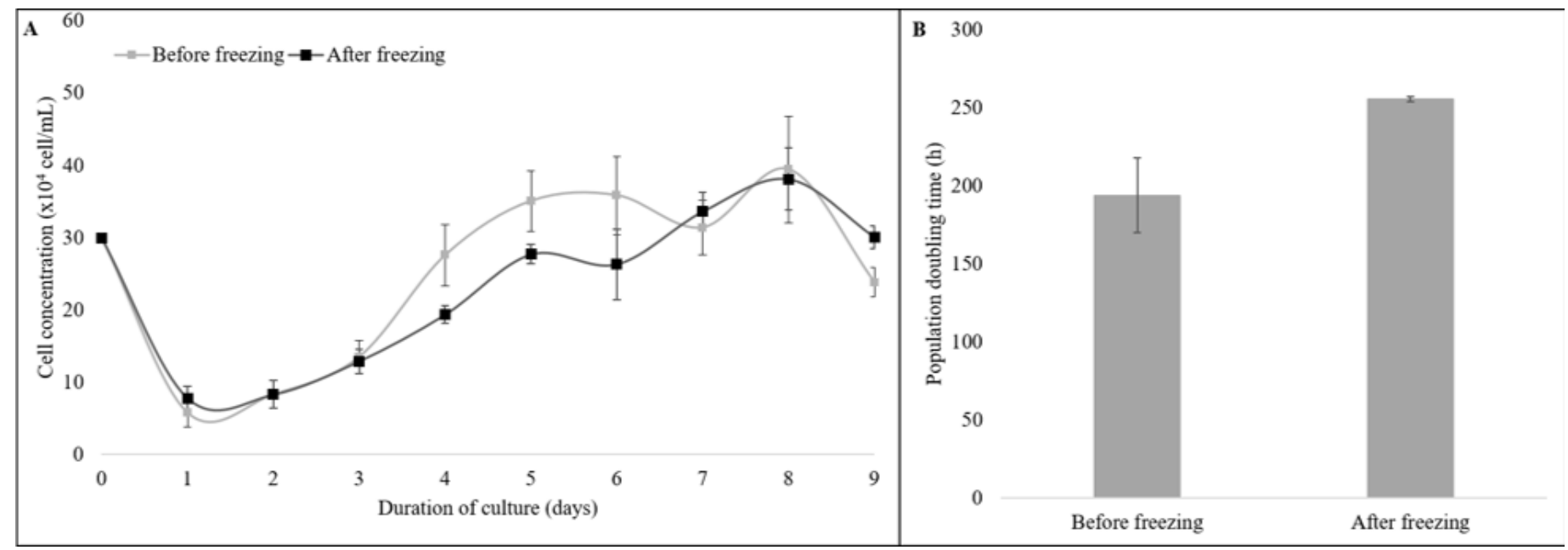




\section{Figure 4}

4 Evaluation of intracellular reactive oxygen species (ROS) and mitochondrial membrane potential $\left(\Delta \Psi_{\mathrm{m}}\right)$.

Cell stained using fluorescent probe A) 2', 7'-dichlorodihydrofluorescein diacetate (H2DCFDA) and B) MitoTrackerRed ${ }^{\circledR}$ (CMXRos) (x10). Quantification of C) ROS and D) $\Delta \Psi$ m levels. Scale bar $=10 \mu \mathrm{m} .\left(^{*}\right)$ Indicate statistical difference $(P<0.05)$.

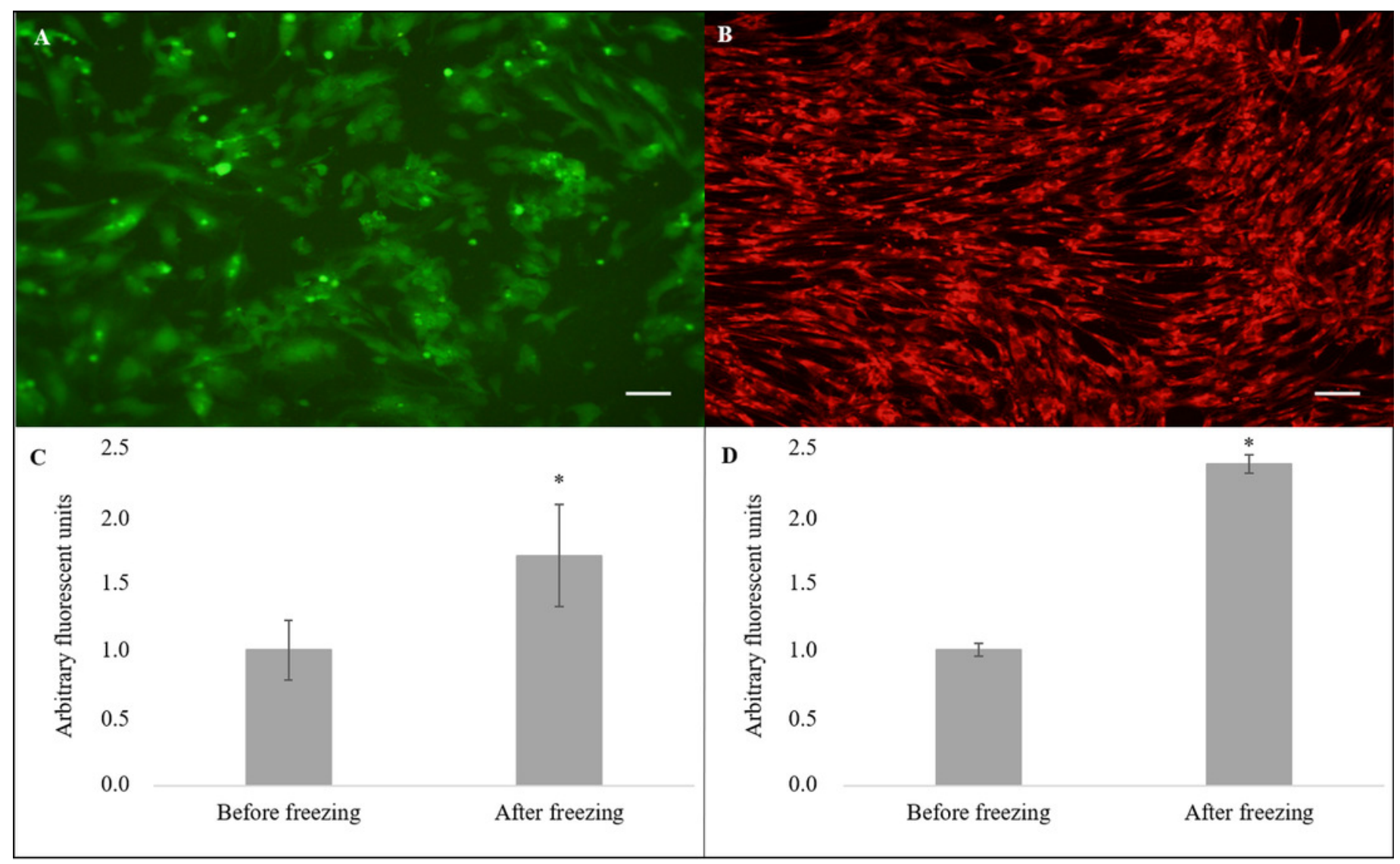




\section{Table $\mathbf{1}$ (on next page)}

Establishment of primary culture and subcultures of somatic cells derived from collared peccary ear skin. 
1 Table 1 Establishment of primary culture and subcultures of somatic cells derived from collared peccary ear skin.

\begin{tabular}{|c|c|c|c|c|c|c|}
\hline \multirow[t]{2}{*}{ Animal } & \multicolumn{3}{|c|}{ No. samples } & \multicolumn{3}{|c|}{ No. of attached samples } \\
\hline & Initial & Attached $(\%)$ & $\begin{array}{l}\text { Day all } \\
\text { attached } \\
\text { explants }\end{array}$ & $\begin{array}{c}\text { Grow to } \\
\text { subconfluence }(\%)\end{array}$ & $\begin{array}{c}\text { Day all cell } \\
\text { grow explants }\end{array}$ & $\begin{array}{l}\text { Subconfluence total } \\
\text { time (days) }\end{array}$ \\
\hline F1 & 4 & 100 & 2 & 100 & 4 & 6 \\
\hline $\mathrm{F} 2$ & 4 & 100 & 2 & 100 & 4 & 5 \\
\hline F3 & 4 & 100 & 1 & 100 & 3 & 9 \\
\hline F4 & 4 & 100 & 3 & 100 & 5 & 10 \\
\hline M1 & 4 & 100 & 4 & 100 & 7 & 9 \\
\hline Mean \pm S.E & 20 & 100 & $2.4 \pm 0.5$ & 100 & $4.6 \pm 0.7$ & $7.8 \pm 1.0$ \\
\hline
\end{tabular}

2 